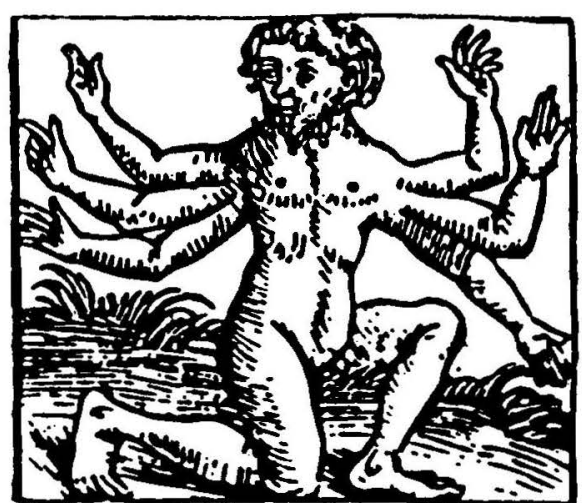

Seks-armet mand

\section{Myteanalyse - analysemyte}

\author{
Lingvistikken som alibi i Lévi-Strauss' \\ strukturelle antropologi ${ }^{1}$
}

\section{JøRN BOISEN}

\section{Strukturalismens arv}

Er det stadig umagen værd at beskæftige sig med den lingvistiske drejning, som en række af humanioras discipliner tog dengang i tresserne? De humanistiske videnskaber har med sine nyeste landvindinger (eller moder, om man vil) fjernet sig fra tressernes epistemologiske problematik. Det har længe været banalt at drage strukturalismens metoder og resultater i tvivl, så hvad er der at gøre andet end at vende ryggen til det gamle paradigme og glemme de begreber, der fejlagtigt virkede så effektive?

Men hvor død er strukturalismen egentlig? Det er rigtigt, at strukturalismen som bevægelse mistede sit momentum, da tre af dens hovedfigurer, Barthes, Foucault og Lacan, forsvandt (som om humanioras udvikling hang sammen med den arkaiske rytme givet af de dynastiske overhoveders liv og død). Men en del af strukturalismens tankegods lever stadig videre i humanioras videnskabelige paradigme, et andet og pænere ord for den uspecificerede blanding af strukturel semiotik, kognitivisme, hermeneutik og postmodernisme som præger den universitære kritik. De store navne - de ovennævnte sammen med Derrida, Greimas, Lévi-Strauss - udgør således stadig en solid reference. De citeres med veneration i enhver tekstanalyseopgave med respekt for sig selv, de er et Sesam-luk-dig-op, gådefulde garanter for en højere sandhed, de udgør kort sagt postmodernismens svar på bibelordet. 
Efter storhedstiden i tresserne og halvfjerdserne blev de strukturalistiske modeller udsat for berettiget knitik fra mange sider først og fremmest fordi de avancerede koncepter, de stringente analyser og diagrammer, de matematiske ligninger osv. ofte viste sig at give ret trivielle resultater. Da den første messianistiske periode, hvor man troede, at videnskabeligheden endelig var kommet til humaniora, var overstået, faldt den strukturalistiske souffle nærmest sammen af sig selv.

Men paradoksalt nok levnede den bizarre vekslen mellem den første entusiasme, den senere afvisning, den nuværende ligegyldighed iblandet en stiltiende accept ikke meget plads til det egentlige: en kritisk intern analyse af det strukturaliștiske episterne. Der findes tusindvis af sider om, hvordan modellerne forholder sig til deresgenstandsområder (myter, litteratur, mode og andre tegnsystemer). Men når det gælder forholdet mellem den lingvistiske metode, man påberåber sig, og så den faktiske teoridannelse, så har strukturalismens egne, naturligvis stærkt farvede erklæringer langt hen ad vejen stået til troende.

Den gren, der i den henseende er mest interessant, kunne man kalde den scientistiske strukturalisme, hvis hovedfigurer var antropologen Levi-Strauss, semantikeren Greimas og litteratur- og billedforskeren Barthes (i hans tidlige periode). Det var først og fremmest disse teoretikere og deres disciple, der ophøjede lingvistikken til en modeldisciplin. Eftersom alt var tegn, kunne alt afkodes videnskabeligt. . De troede oprigtigt, at Saussures, Hjelmslevs og Jakobsons lingvistik kunne tilbyde den bedste metodologi inden for humaniora, og de brugte en betragtelig mængde energi på at udvikle forskellige anvendelser i deres respektive discipliner. De havde det til fælles, at de ikke var sprogforskere,2 selvom de måske ikke beskæftigede sig med meget andet end sprog. Når de stødte på mangler ved den oprindelige lingvistiske model, fors øgte de hver især med ad hoc løsninger at lappe på den uden dog nogensinde at drage dens fundamentale gyldighed i tvivl,

Da lingvistikken blev betragtet som en radikalt anderledes og bedre metodologi af den scientistiske strukturalisme, var de forskellige strukturalistiske teorier naturligt akkompagneret af en militant retorik, der dekreterede slutningen på de tidligere, mindre videnskabelige epistemeer. Alt var tegn, alt kunne derfor afkodes videnskabeligt og derfor var der ikke længere brug for de forskellige discipliners traditionelle epistemologjer. Som nævnt blev denne påståede videnskabelighed generelt. accepteret. Det interessante er imidlertid, at man ikke behøver at analysere den tịlsyneladende ubønhørlige logik ret meget, før man opdager, at de scientistiske strukturalister i flere tilfælde bevæger sig væk fra enhver strukturalisme, og at argumentationen under alle omstændigheder forholder sig fuldstændig frit til sit epistemologiske udgangspunkt, lingvistikken og mere præaist fonologien.

Den fonologiske revolution

Det er anvendelsen af lingvistikkens metoder uden for lingvistikkens egentlige domæne, der definerer strukturalismen som bevægelse. Den scientistiske gren af strukturalismen er f rst og fremmest fokuseret på videnskabelighed. Som astronomIen engang var blevet underlagt materriatikkens og fysikkens 10v-e, drømte strukturalismen om at underlægge de bløde humamstiske videnskaber lingvistikken, „la seule, sans doute, qui puisse revendiquer le nom de science".3Med Saussure var lingvistikken nemlig blevet en rigtig videnskab i lighed med de naturviden-skaber, som strukturalisterne misundeligt skævede til. Saussures erklæring om at lingvistikken skulle være "skytshelgen for enhver semiologi" 4 blev taget yderst bogstaveligt. .

Dette er tydeligt i strukturalistiske tekster, som fx. LeviStrauss' banebrydende artikel "L'analyse structurale en linguistique et en anthropologie",5 hvor han argumenterer for $\sim \mathrm{t}$ antropologen, hvis han følger lingvistens eksempel, ogsa kan gennemføre den "fonologiske revolution" inden for sin disciplin.

Med den fonologiske revolution mente Levi-Strauss arbejdet med at finde frem til det system, der ligger under talesprogets lyde, som Prager-skolen anført af Jakobson og Trubetzkoy havde udført. Trubetzkoy skelnede mellem studiet af faktiske talte lyde (fonetik) og undersøgelsen af de lydaspekter, der er funktionelle i et givet sprog (fonologi). Fonologien skulle: 
undersøge, hvilkefoniskeforskelleder i det givne sprog er kædet sammen med meningsforskellehvordan disse differentierendeelementer eller marker er indbyrdes forbundet og $\sim$ fterhvilken regel de kombineres til ord og sætninger. 6

Da lingvistikken udgør selve strukturalismens fundament, er det også her (som allerede Paul Ricæur bemærkede)7 man må koncentrere sine analyser, hvis man vil forstå og vurdere strukturalismen og dens metoder. Claude Levi-Strauss er i dette perspektiv særlig interessant, ikke blot fordi han var en af de første, der med stor energi og konsekvens gik i brechen for de lingvistiske principper, men også fordi hans teorier fandt en praktisk anvendelse i et monumentalt . værk, der står som det til dato mest vidtfavnende og imponerende eksempel på en strukturel analyse.

Levi-Strauss' myteanalyse

Det er Levi-Strauss' storslåede ambition at samle og sammenligne myter fra forskellige kontinenter for at vise deres lighedstræk og dermed kortlægge menneskesindets grundlæggende mekanismer. Levi-Strauss hævder, at menneskesindet både på det bevidste og ubevidste plan giver form og struktur til enhver form for erfaring. Hvis man vil undersøge disse strukturer, er myter det ideelle materiale, for på:de fleste områder er det nemlig svært at skelne, hvilke strukturer der er bestemt af mentale operationer, og hvilke der skyldes ydre tvang. Men i myternes rige er der ingen ydre tvang, for alt kan i princippet ske i en myte. Derfor kan man, hvis man er i stand til at opdage og beskrive det system, der ligger under myterne, tilskrive dette system selve menneskesindet:

Hvis man kunne vise, at det vilkårligeydre udtryk, det såkaldt frieudspring, den tilsynela,dend®øjlesløsefantasiogså i dette tilfældeforudsætter love, der virker på et dybereniveau, må konklusionenuundgåeligtblive, at sindet, når det stillesansigttil ansigtmed sig selvog således ikke længerebehøver at tage hensyn til ting, på en elleranden måde reduceres til at efterlignesig selv som ting, og da lovenefor denne måde at operereikke er fundamentalt forskelligefra dem, som det afslører den anden funktion, så viser det sin natur som ting blandt andre ting. 8
Såvel værkets dimensioner som dets stort anlagte ambition gør det umuligt at yde det nogen som helst form for retfærdighed på et par sider. Det, som man derimod kan gøre, er at undersøge, hvordan værket $i$ en konkret analyse forholder sig til sine epistemologiske præmisser, nu da lingvistikken rent faktisk er en videnskab, hvor resultaterne kan verificeres og falsificeres.

Levi-Strauss' yndlingsmetafor er sproget.. Og hovedtemaet i Anthropologie structurale er analogien mellem antropologi og lingvistik.. Ifølge Levi-Strauss udgør al opførsel et sprog, et ordforråd og en grammatik.. Det, som Levi-Strauss især overtog fra den fonologiske revolution, var ideen om, at man ikke kunne betragte de forskellige elementer som uafhængige enheder men som dele af et system, og det var udelukkende relationerne mellem elementerne, der kunne undersøges. ${ }^{9}$

I sin analyse af Odipusmyten fx. insisterer han på, at de forskellige begivenheder (det forsvundne barn, den gamle mand ved skillevejen, sfinksens tilintetgørelse, brylluppet med moderen etc.) intet betyder. Kun når de sættes sammen i hele konteksten, får de en mening, nemlig den mening, som bliver genereret af en logisk model.. Ved at give mytens elementer en bestemt betydning, så begår teoretikerne (Jung fx. med sine arketyper) en fejl, der kan sammenlignes med den, Sokrates begår, når han i Kratylos tillægger lyde en bestemt mening: " $r$ " som udtryk for bevægelse, „I" for en glidning, åbne vokaler for store og tunge ting, osv.

Lingvistikkens største succes er opnået inden for den strukturelle fonologi, hvor det har været muligt at vise, at lydene i et sprog, skønt fuldstændig blottede for mening, alligevel udgør et betydningssystem. Fonemer er netop defineret som rene udtryksstørrelser uden selvstændig mening, men med en distinktiv funktion. Derfor, fortsætter Levi-Strauss, har myteantropologien ikke noget andet valg, hvis den også vil opnå status af videnskab, end at efterligne de fonologiske fremgangsmåder.

Ligesom lydene, der er samlet $i$ et ord, ikke har nogen uafhængig betydning (eftersom det kun er konventionen der gør, at $\mathrm{h}, \mathrm{u}, \mathrm{n}, \mathrm{d}$ betyder hund), således optræder også elementerne, der indgår $\mathrm{i}$ en myte, arbitrært uden forbindelse med den historie, 
som myten tilsyneladende fortæller. På samme måde som fonemerne organiserer sig i abstrakte systemer uafhængigt af de udtalte sekvenser, så er det ikke fortællingen i selve myten, der giver betydningen, for under fortællingen er der nemlig et skema, hvis grundelementer afslører mytens hemmelighed. Dette skema finder antropologien frem til via lingvistikkens konceptuelle redskaber.

\section{Intet over og intet ved siden af lingvistikken}

Allerede før Lévi-Strauss havde der været et vist metodefællesskab mellem lingvistik og antropologi, men dette havde været begrænset til disciplinernes mindst problematiske aspekter såsom de forskellige teknikker til indsamling af data, og LéviStrauss havde ikke tænkt at lade sig nøje med rollen som en beskeden data-indsamlende observatør. Det egentlige metodefællesskab som Lévi-Strauss vil indføre er et stort skridt mod økonomiens, neurologiens og lingvistikkens forjættede land. Der skal renses ud og ryddes op i antropologien og den helt store kost er lingvistikken. Der er andre interessante aspekter ved dette valg, først og fremmest en tydelig polemisk intention, idet LéviStrauss mere eller mindre implicit placerer alle, der ikke benytter den nye metode, samt alle, der ikke omvender sig til den, i førvidenskabelighedens triste limbo.

Lévi-Strauss finder hos Saussure en moderniseringsmodel, der nemt kan overføres til andre sociale videnskaber. Derfor insisterer han på lingvistikkens absolutte metodologiske forrang inden for humaniora. Det gør han bl.a. ved at præsentere Saussures tegnmodel som en revolutionær opdagelse, der gør ende på århundreders vildfarelser. Sandheden er nok snarere, at der blot er tale om en generalisering af traditionel lingvistisk praksis. At tegnet er arbitrært er noget der på sin vis længe har ligget implicit i hele den lingvistiske tradition. Såvel grammatikere som sproghistorikere havde siden Rasmus Rask arbejdet med sprogets formelle aspekter adskilt fra den kontekst, der omgiver og bærer det. At tegnet er arbitrært er selve grundlaget for disse traditionelle lingvistiske discipliner: hvordan skulle man ellers kunne bedrive historisk fonetik (der sporer de lydlige ændringer uafhængigt af de semantiske variationer), eller leksikografi (der for den samme lydsekvens kan finde myriader at betydninger) Det er netop, fordi der ikke er nogen nødvendig forbindelse mellem lyd og betydning, at det giver mening at forske i disse og lignende discipliner. Saussure generaliserede blot - med genialt klarsyn - en af den historiske grammatiks accepterede sandheder i sin Cours de linguistique générale.

Lévi-Strauss overtager Saussures, Trubetzkoys og Jakobsons teorier med den nyomvendtes entusiasme. Takket være disse navne havde lingvistikken gjort enorme fremskridt, men LéviStrauss afholder sig fra at diskutere andre samtidige retninger $i$ lingvistikken og fonologien, som om Roman Jakobsons teorier overalt blandt lingvister var accepteret som den bedste for ikke at sige eneste løsning inden for fonologi. Alvorligere er det imidlertid, at Lévi-Strauss ved at insistere på det revolutionerende og det indiskutable i lingvistikkens metodologiske fremskridt på forhånd diskvalificerer diskussionen af de eventuelle problematiske sider ved det metodologiske lån. Der er, som Frans Gregersen bemærker, „en særlig ironi i, at Saussure tages som førstemand og inspirator for en bevægelse der generaliserer fra sprogvidenskab til andre videnskaber. Det var nemlig en af Saussures pointer at sproget var noget særligt. "10 Lévi-Strauss undlader simpelthen at drøfte de epistemologiske konsekvenser, som princippet om det arbitrære tegn vil få for antropologien. De modeller, der gælder i den strukturelle fonologi, påstås simpelthen at være principielt velegnede til analysen af myter.

\section{Fra fonologi til antropologi}

Før Lévi-Strauss havde studiet af myter traditionelt været koncentreret om begreber som motivation og funktion, eftersom formålet var at finde og tolke de forbindelser, der findes mellem myterne og den moralske eller sociale erfaring, som de udtrykker. Hvor lingvisterne aldrig har forsøgt at etablere andet end en vilkårlig forbindelse mellem lyden /hund/ og betydningen "hund", så havde antropologerne tværtimod bestræbt sig på at bestemme naturen af den motiverede forbindelse (som aldrig 
blev draget i tvivl) mellem myten og dens moralske mening og sociale funktion.

Lévi-Strauss vender op og ned på denne opfattelse. Han behandler myter som en rent formel mental operation uden noget psykologisk indhold og uden forbindelse med religiøse riter. Fortællingerne er logiske indretninger med det formål at tematisere og eventuelt mediere reglerne $i$ det sociale spil, når disse giver anledning til spændinger eller modsigelser.

Saussures lingvistik bliver hos Lévi-Strauss en løftestang, der løfter myterne ud af det net af motivationer, hvori de indtil da var blevet tolket og forstået af den antropologiske tradition. Ambitionen om at modernisere antropologien går, via lingvistikken, over en fremmedgørelse af studieobjektet, „une technique de dépaysement", som han kalder det i Anthropologie structurale. Efter at have tømt myterne for betydning vil Lévi-Strauss anlægge en radikalt ny betydningsstruktur, en struktur med grundlag i den strukturelle fonologi.

Lévi-Strauss hævder, at myter ligesom tegn er konstitueret af to sider, hvis indbyrdes forhold er arbitrært. Gemt bag ved fortællingen findes der en anden struktur, et grundlæggende niveau som bestemmer overfladeniveauets struktur og betydning. Forholdet mellem disse to niveauer er arbitrært. Derfor må man, hvis man vil bestemme det fundamentale niveau, anvende de fremgangsmåder, der i fonologien med så stor succes har kunnet reducere sprogets utallige fremtrædelsesformer til det system, der ligger under det.

\section{En fonologisk analyse af Ødipusmyten}

Hvis man blot nøjes med at læse historien, bliver man offer for den samme illusion som mytens brugere, hævder Lévi-Strauss. Fortællingen er en række af vilkårligt blandede elementer, som antropologen skal bestemme og bringe i orden for at forstå dem. Lévi-Strauss sammenligner dette arbejde med at rekonstituere et orkesterpartitur ud fra et nodeark, hvor de forskellige orkesterstemmer er sat vilkårligt i en række efter hinanden (musikken er, efter sproget, Lévi-Strauss' yndlingsmetafor).
Dette rekonstituerede orkesterpartitur ser for Ødipusmyten således ud:

Kadmos søger sin søster Kadmos dræber dragen der er bortført af Zeus

Spartanerne dræber

hinanden

Labdakos betyder “halt”

Laios betyder

„kejthåndet"

Ødipus dræber sin far

Ødipus tilintetgør sfinksen

Ødipus gifter sig

med sin mor Jokaste

Ødipus betyder

"svullen fod"

Eteokles dræber sin

bror Polyneikos

Antigone bryder loven

og begraver Polyneikos ${ }^{11}$

Myten fortælles ved at læse linierne fra venstre til højre og oppefra og ned: først leder Kadmos efter sin søster Europa, så dræber han dragen, dernæst dræber spartanerne hinanden etc. Disse segmenter følger historiens kronologi (som Lévi-Strauss kalder diakronien). En egentlig forståelse af mytesystemet når man imidlertid først, når man sammenligner de fire lodrette spalter (der af Lévi-Strauss kaldes synkronien). Lévi-Strauss når i sin analyse frem til, at de fire spalter betyder henholdsvis „overdrevne slægtskabsbånd" (Kadmos' kærlighed til sin søster, Ødipus' incest, Antigones kærlighed til sin døde bror), „for svage slægtskabsbånd" (spartanerne der dræber hinanden, Ødi- 
pus der dræber sin far, Eteokles der dræber Polyneikos), „uhyrer der dræbes“ (dragen, sfinksen) og "problemer med at gå og holde sig oprejst“ (antydet af proprierne Ødipus, Labdakos, Laios).

Lévi-Strauss hævder så, at de to første spalter drejer sig om gode og dårlige slægtsbånd, mens de sidste to spalter henholdsvis bestrider og hævder menneskets slægtskab med jorden. LéviStrauss begrunder den noget overraskende tolkning af de to sidste spalter med at uhyrerne, der dræbes, er jordskabninger, mens det gangbesvær, som proprierne antyder (Ødipus $=\varnothing \mathrm{m}$ fod, Labdakos = halt), er et tegn på menneskets utilstrækkelige frigørelse fra jorden. Mellem disse begreber, der hver følges af sin egen negation, etableres et analogiforhold der kan udtrykkes på denne måde: overdrevne slægtskabsbånd forholder sig til underdrevne slægtskabsbånd som menneskets forsøg på at gøre sig fri af sin jordiske herkomst forholder sig til umuligheden af en sådan frigørelse. Denne analogi skulle være et forsøg på at mediere en spænding over for et problem, der i den kultur der skabte myten forekom uløseligt:

Den udtrykker hvor umuligt det er for et samfund, der hævder at tro på menneskes jordiske herkomst, at gå fra denne teori til en accept af at hver af os i virkeligheden fødes af en mands og en kvindes forening. ${ }^{12}$

Under Lévi-Strauss' skema genkender man let den lingvistiske model med dens koncentration om binære funktionelle modsætninger. Lévi-Strauss finder mytens egentlige betydning ved at modstille elementer, der isoleret ikke giver mening. Den fonologiske fremgangsmåde er instrumentet og garanten for, at de myteelementer, der behandles, vitterlig har denne betydning, der ligger uendelig fjernt fra det, som alle andre naivt går rundt og tror, at de betyder.

Hele analysen bygger på to aksiomer. Det første siger at myten er et lingvistisk fænomen, der ganske vist har en række særlige, temmelig komplekse egenskaber, men som ikke desto mindre kan analyseres og tolkes som andre lingvistiske fænomener. Dette første aksiom er en slags tilkendegivelse af og en be- grundelse for, at man vil anvende lingvistikken, nærmere betegnet fonologien, som analysemodel. Det er en metodologisk programerklæring, som man som sådan ikke kan indvende noget imod.

Det andet aksiom går ud på at mytens betydning ikke ligger i selve fortællingens kronologiske udvikling, men i myten som helhed, en helhed hvor de enkelte elementer ikke har nogen uafhængig betydning. Dette er ikke en programerklæring, men en erklæring om mytens natur. I modsæetning til programmer og manifester kræver man normalt, at sådanne konstateringer af empirisk karakter bliver underbygget af en argumentation og en undersøgelse, der godtgør deres sandhedsværdi. Hos LéviStrauss er det imidlertid ikke konklusionen på analysen men tværtimod det metodologiske - for ikke at sige ideologiske - udgangspunkt for analysen. Hvad mere er: aksiomet om at mytens forskellige elementer ikke skulle have nogen uafhængig betydning, er i virkeligheden ikke andet end en konsekvens af den foregående beslutning om at anvende fonologiske metoder i myteanalysen, eftersom fonemer jo netop er karakteriseret af, at de ikke har nogen selvstændig betydning. Det vil med andre ord sige, at Lévi-Strauss begår en klassisk fejl: det er målemetoden, der bestemmer resultatet af målingen.

Også selvom man accepterer lingvistikkens metodologiske almengyldighed, er overførslen af dens begrebsapparat til antropologien temmelig problematisk, for at sige de mildt. For efter hvilke principper sker denne overførsel? Og hvorfor har LéviStrauss netop beluttet sig for en fonologisk funderet analyse af myterne? Hvorfor bestemme, at mytens hændelser opfører sig som de betydningstomme fonemer og ikke som ord, syntagmer eller sætninger i en tekst? (et spørgsmål som allerede Paul Ricœur formulerede). For selvom forbindelsen mellem tegnets signifiant og signifié er arbitrær, og selvom fonemerne hver for sig ikke betyder noget, så afhænger sproglige ytringers betydning stadig af, hvad deres forskellige elementer betyder og det helt fra de elementære niveauer som grammatiske endelser og præ- og suffikser til ord- syntagme- og sætningsniveauet. Hvorfor har 
myteanalysen netop behov for en fonologi og ikke for en morfologi, en syntaks, eller måske bare et leksikon?

\section{Lévi-Strauss og den fonologiske metode}

Lévi-Strauss' begrundelse for at indføre netop de fonologiske metoder er, at de havde nået en høj grad af systematisering og præcision. Men hvordan forholder Lévi-Strauss sig egentlig til de fonologiske metoder, som han priser så højt? Fonologien har til formål at oversætte fonetiske sekvenser til sekvenser af fonemer, træk, der inden for systemet er betydningsbærende. Denne oversættelse er underlagt en række teoretiske krav, der skal sikre at fonologen behandler de empiriske data på en videnskabeligt forsvarlig måde. I Current Issues in Linguistic Theory fra 1964 formulerer Chomsky ${ }^{13}$ disse klassiske krav til den fonologiske analyse som fem punkter: fonetisk specifikation (phonetic specifiability), linearitet (linearity), invarians (invariance), dobbelt entydighed (biuniqueness), lokal bestemmelse (local determinacy). Disse kriterier stilles i Chomskys analyse temmelig firkantet op, da hans pointe netop er at vise, at det er umuligt at overholde dem fuldstændigt. Pragerskolen betragtede imidlertid ikke disse betingelser som absolutte krav, men snarere som overordnede principper, der tillod visse undtagelser. Det, der i denne sammenhæng er vigtigt, er, at de forskellige kriterier, skønt de ikke er absolutter, ikke desto mindre udstikker nogle generelle retningslinier for den fonologiske analyse. Det er som sådan, at de kan bruges til at teste videnskabeligheden af Lévi-Strauss' myteanalyse.14

Den fonetiske specifikation kræver, at „en generel lingvistisk teori skal indeholde en universel fonetisk teori med et fast alfabet" ${ }^{\prime 1}$ Dvs. at fonologen for at udføre sit arbejde ordentligt først må give en præcis fonetisk beskrivelse af det råmateriale, som han arbejder med. I myteanalysen svarer det til, at man først udarbejder en global teori om det mytologiske materiale. Men hvad er det mytologiske råmateriale egentligt? De enkelte begivenheder? De genkommende motiver? Arketyperne? Jeg ved det ikke og det gør Lévi-Strauss heller ikke. Eller hvis han gør, så fortæller han det ikke. Der findes simpelthen ikke noget hos ham, der svarer til et fonetisk niveau, hvorpå den fonologiske beskrivelse kunne grundlægges. Lévi-Strauss har så at sige udviklet noget så originalt som en fonologi uden fonetik.

Som den klassiske fonologis andet kriterium angiver Chomsky kravet om linearitet. Det går ud på, at faktorernes orden ikke er ligegyldig.

Betingelsen om linearitet kræver, at enhver forekomst af et fonem i den fonemiske repræsentation af en ytring bliver forbundet med en særlig rækkefølge af (en eller flere) på hinanden følgende sproglyde i den repræsenterende matrice som dens "medlem" eller "realisering"; og yderligere at, hvis $\mathrm{A}$ kommer før $\mathrm{B}$ i den fonemiske repræsentation, så skal sproglydssekvensen, der er forbundet med A, komme før (stå til venstre for) den, der er forbundet med $\mathrm{B}$ i den fonetiske matrice. 16

Den indbyrdes rækkefølge i en fonologisk beskrivelse af en ytring skal element for element svare til den fonetiske beskrivelse af samme ytring. Der skal være streng kronologisk parallellisme mellem fonetikken og dens fonologiske repræsentation, mellem de konkrete elementer og deres abstrakte billede. Dette krav virker så umiddelbart indlysende, at man forbavses over at se Chomsky formulere det med en sådan omhu. Ikke desto mindre bliver kravet fuldstændig ignoreret af Lévi-Strauss.

Det er selvfølgelig vanskeligt at vurdere lineariteten, da der ikke er nogen eksplicit teori om, endsige analyse af, mytens råmateriale. Lévi-Strauss' faktiske analyse indicerer imidlertid, at han opfatter begivenhederne som mytens grundniveau (det "fonetiske" niveau). I hvert fald er hans fire spalter baseret på (nogle af) mytens begivenheder. Hvis man verificerer lineariteten mellem de to beskrivelsesniveauer, ser man, at den rent faktisk bliver respekteret i de tre første spalter. Til følgende begivenhedssekvens på det ",fonetiske"17 niveau „Ødipus dræber sin far, så tilintetgør Ødipus sfinksen, så gifter Ødipus sig med sin mor" svarer denne sekvens på det "fonologiske" niveau "for løse slægtskabsbånd følges af nægtelse af menneskets jordiske herkomst følges af for tætte slægtskabsbånd".

Hvis man derimod ser på 4. spalte, så gælder lineariteten ikke længere, for elementerne her tilhører ikke handlingsplanet. Sekvensen „Ødipus tilintetgør sfinksen, dernæst betyder Ødipus 
øm fod" er ikke lineær. Lingvistikken kan sagtens behandle sådanne fænomener, som ikke befinder sig på et givet sted $\mathrm{i}$ kæden af fonemer, men den gør det karakteristisk nok på et andet niveau end det fonologiske. Lévi-Strauss blander beskrivelsen af to forskellige typer elementer sammen i sin analyse på en måde, der ville være uacceptabel i en fonologisk analyse. Hans rekonstitution af myten respekterer ikke kravet om linearitet.

Det 3. krav til den fonologiske analyse stipulerer, at den samme lyd ikke kan være det fonetiske udtryk for to forskellige fonemer. Det er det, Chomsky kalder kravet om invarians:

Betingelsen om invarians hævder, at ethvert fonem $\mathrm{F}$ er forbundet med et bestemt sæt ${ }^{\boldsymbol{\Psi}}(\mathrm{F})$ af definerende træk (det vil sige, $\mathrm{F}=\mathrm{Q}$ hvis og kun hvis $\Psi(F)=\Psi(\mathrm{Q})$ ) og, at hvor $\mathrm{F}$ end forekommer $\mathrm{i}$ en fonemisk repræsentation, er det forbundet med en forekomst af $\Psi_{(F)}$ i den tilsvarende fonetiske repræsentation. 18

Visse lingvister ( $\mathrm{fx}$. Jakobson) accepterer en vis overlapning i den fonologiske repræsentation, uden at dette dog ændrer væsentligt ved det, der er formålet med kravet: at minimisere det vilkårlige $i$ analysen og sørge for en solid sammenhæng mellem det empiriske grundlag og den teoretiske konstruktion. Hvert element på det konkrete niveau skal henvise til ét og kun ét element på det abstrakte niveau. Det er på denne måde, at en lyd, når den først er blevet knyttet til et fonem, ikke kan repræsentere andet end dette fonem. Endnu en gang er det næsten omsonst at undersøge dette i Lévi-Strauss' analyse, da der ikke findes noget eksplicit empirisk grundlag, og da kravet om linearitet ikke respekteres (, Kravet om invarians giver ikke mening, medmindre kravet om linearitet også er opfyldt", ${ }^{19}$ skriver Chomsky), men lad os prøve alligevel.

I analysen kommer drabet på en nær slægtning fx. til at repræsentere den abstrakte kategori "for løse slægtskabsbånd" og omvendt skal kategorien ",for løse slægtskabsbånd" hver gang vise tilbage til et drab mellem slægtninge på handlingsplanet. Sådan går det rent faktisk et stykke af vejen. Det er på denne måde, at Lévi-Strauss finder frem til den 2. spalte i sit skema. Det er imid- lertid klart, at kravet om invarians kun kan respekteres, hvis de forskellige teoretiske enheder er præcist definerede. Hvis man $\mathrm{fx}$. tager den abstrakte kategori ",for tætte slægtskabsbånd", finder man følgende konkrete manifestationer: Kadmos leder efter sin søster, som Zeus har bortført; Ødipus gifter sig med sin mor; Antigone begraver sin bror Polyneikos. Dvs. at den samme abstrakte kategori rummer to så vidt forskellige handlinger som 1) at tage en velovervejet beslutning om at begrave sin bror og derved respektere de guddommelige love og 2) at gifte sig med en ukendt kvinde, som senere viser sig at være ens mor, og derved forbryde sig mod de guddommelige love. At placere disse to handlinger i samme kategori vidner om en noget begrænset følsomhed over for spillet mellem ligheder og forskelle.

I den strukturelle lingvistik styrkes sammenhængen mellem det empiriske grundlag og den teoretiske konstruktion også af kravene om dobbelt entydighed og lokal determination: den dobbelte entydighed sikrer, at man kan udlede de fonologiske repræsentationer og de fonetiske transskriptioner af en givet ytring af hinanden, ved at kræve at „enhver sekvens af sproglyde bliver repræsenteret af en unik sekvens af fonemer, og at enhver sekvens af fonemer repræsenterer en unik sekvens af sproglyde. ${ }^{20}$ Til sidst sørger kravet om lokal determination for at man undgår at gøre brug af sin grammatiske viden i den fonologiske analyse, „således at den unikke fonemiske repræsentation, der svarer til en given fonetisk form, kan bestemmes af "rent fonetiske“ overvejelser eller muligvis overvejelser, der kun indblander lyde i umiddelbar nærhed." ${ }^{21}$ Det vil fx. sige, at man rekonstituerer rækken af fonemer uden på forhånd at kende inddelingen af fonemerne $i$ ord.

Disse to sidste betingelser sikrer at reglerne for, hvordan man kommer fra det ene niveau til det andet, konstrueres på en sådan måde, at der til enhver fonetisk beskrivelse kun svarer én fonologisk repræsentation og omvendt. I praksis har det imidlertid vist sig, at der er en vis asymmetri mellem de to niveauer: overgangen fra den fonologiske repræsentation til den fonetiske beskrivelse ved hjælp af de fonologiske regler er mere entydig end overgangen fra fonetikken til fonologien, dvs. at man for en fone- 
tisk sekvens af og til vil kunne finde mere end én fonologisk repræsentation.

Det er måske ikke overraskende, at Lévi-Strauss heller ikke respekterer disse to krav til fonologien i sin analyse. Mere overraskende er det, at asymmetrien hos ham er omvendt. Her er det overgangen fra det abstrakte til det konkrete plan, der giver problemer og ikke omvendt. Lévi-Strauss udtrykker ikke explicit de regler, som han anvender, men man kan foretille sig, hvordan de må se ud: hver gang man for eksempel støder på et drab på en slægtning, skriver man symbolet "for løse slægtskabsbånd“; hver gang der bliver dræbt et uhyre, skriver man „negation af menneskets jordiske herkomst." Fire sådanne regler giver analysens fire lodrette spalter og en femte og sidste regel kunne så foreskrive, at man ikke skulle tage højde for alle de begivenheder, der ikke er blevet tildelt et symbol. Hvis man derefter placerer elementerne, der er mærket med samme symbol, oven over hinanden, får man Lévi-Strauss' skema.

Til gengæld er det komplet umuligt at udføre den modsatte operation. Man kan ikke gå fra skemaet til myten ved hjælp af de regler, vi her har defineret. Der er ingen dobbelt entydighed. Der er blevet slettet alt for mange af mytens elementer, til at man nogensinde vil kunne rekonstituere dem ved hjælp af Lévi-Strauss' regler. Hvis man prøver, får man ikke andet end en temmelig uforståelig række af begivenheder og proprier.

Det, der især har generet mange kritikere, er, at mange af de begivenheder, der normalt betragtes som essentielle i myten, udelades i Lévi-Strauss' analyse. Han argumenterer imidlertid for, at de sagtens kunne finde en plads i den. Det gælder fx. Jokastes selvmord og Ødipus, der straffer sig selv ved at stikke sine øjne ud. Den første hændelse kunne finde sin plads i 3. spalte som tilintetgørelsen af endnu en jordskabning, og den anden i 4. spalte som en bekræftelse af propriernes indikationer af handicap og gangbesvær. Lévi-Strauss hævder endda, at dette gør myten mere eksplicit. ${ }^{22}$

Denne uventede tolkning går naturligvis ikke blot imod den tusindårige opfattelse af disse handlinger som et forhold om skyld og viden. Den udgør også et eklatant brud på reglerne om den dobbelte entydighed og den lokale determination, idet den sprænger enheden i $2 . \operatorname{og} 4$. spalte, to forholdsvis ensartede kategorier. I 2. spalte bliver selvmordet rangeret sammen med tilintetgørelsen af forskellige uhyrer, mens Ødipus, der stikker sine øjne ud, placeres sammen med proprierne, der antyder et handicap.

Lingvister skal kunne være i stand til ved hjælp af systemets regler at genskabe den konkrete lydsekvens ud fra den fonologiske gengivelse. Det kunne være interessant at se nogen rekonstituere Ødipus-myten udfra Lévi-Strauss' abstrakte repræsentation.

Når man tænker på, at Lévi-Strauss' begejstring for den klassiske fonologi er baseret på beskrivelsernes præcise empiriske grundlag og den konstante og aldrig svigtende omhu for principperne om verifikation og videnskabelighed, hvad skal man så tænke om hans egen myteanalyse? Det er tydeligt, at LéviStrauss ikke selv har tænkt sig at lade sit analyseapparat køre fast i fonologiens formelle krav til sine analyseprocedurer. Det er i det hele taget forbavsende at se, at den ildhu, hvormed Lévi-Strauss propaganderer for indførelsen af fonologiske metoder, nærmest er omvendt proportional med den rent faktiske anvendelse af disse metoder. Hele programerklæringen med Saussures tegnbegreb og fonologiens videnskabelighed bliver lynhurtigt undergravet af en praksis, der i høj grad synes styret af Lévi-Strauss' intuitioner, der muligvis er geniale, men som dog er og bliver intuitioner.

\section{Fonologien som fagpolitisk instrument}

Men hvis Lévi-Strauss myteanalyse ikke er fonologisk, hvad er den så? Han skriver, at den strukturelle lingvistik afslører sproghandlingernes ubevidste karakter. Etableringen af et fonologisk system behøver ikke at tage højde for de talendes bevidsthed, og det er måske det, der i sidste ende tiltrækker Lévi-Strauss. Med fonologien kan han gøre rent bord, ikke for at underkaste sig fonologiens strenge krav, men for at diskvalificere sin egen disciplins filologiske og hermeneutiske kontrolinstanser. Brugen af fonologien er først og fremmest polemisk. Lévi-Strauss usurpe- 
rer dens ubetvivlelige videnskabelighed for med den at diskvalificere sine modstandere som prævidenkabelige. Lingvistikken fremstår som et påskud, der gør Lévi-Strauss i stand til at sætte sig ud over traditionen og giver ham fuldstændig frie hænder for da den prætenderer en langt højere grad af videnskabelighed, levner Lévi-Strauss' mytekritik ikke mulighed for en vurdering fra den antropologiske fagtradition.

\section{En moderne gnostiker}

De friheder, der blev taget over for det påberåbte forlæg, syntes underligt nok ikke at have svækket tiltroen til Lévi-Strauss' myteteori i nævneværdig grad. Det gik med den, ligesom det gik en række andre af den scientistiske strukturalismes modeller (Greimas' sommerfuglemodel fx.): trods det uklare epistemologiske grundlag og ganske åbenlyse svagheder i den praktiske anvendelse blev myteanalysen betragtet som slags åbenbaring om myters og litteraturs inderste væsen. I en del af halvfjerdsernes og firsernes litteraturkritik fremstår den med en aura af uimodsigelig sandhed. Endnu engang møder man det arkaiske træk, der synes at kendetegne humaniora. Videnskabsmændene bliver guruer og deres lære lyser med den kraft, der tilhører ikke sandheden, men mysteriet.

Det er rigtigt, at Lévi-Strauss foreslår en ny og interessant læsning af myter, men hans teori er ikke en videreudvikling af den antropologiske tradition mod større videnskabelighed. Snarere tværtimod. Men når vi ikke får en „,fonologisk revolution", hvad får vi så? En form for personlig eksegese som er kendetegnet ved det enorme spring, der er mellem, hvad teksterne tilsyneladende handlede om og den hemmelige betydning, som udlægningen giver. Med andre ord en læsning, der minder om den, som gnostikerne i middelalderen foretog af de hellige skrifter.

I L'Homme $n u$, det sidste bind af det gigantiske myteprojekt, sammenligner Lévi-Strauss myter med musik:

Myterne kan kun oversættes til andre myter, på samme måde som en melodi kun kan oversættes til en anden homolog melodi. [...] Men hvis det altid er muligt [...] at oversætte en melodi til en anden melodi [...] som det også er tilfældet med mytologien, så kan man ikke oversætte musik til noget andet end musik, uden at risikere at synke ned i den gamle mytografis ordflom og hermeneutiske prætentioner, noget der også alt for ofte gælder musikkritikken. Den ubegrænsede frihed til at oversætte til alle dialekterne i et oprindeligt sprog, der tilsammen danner et lukket univers, går således hånd $\mathrm{i}$ hånd med den radikale umulighed af at transponere det til et sprog udefra. ${ }^{23}$

Hvis man prøver at forklare myterne, ender man i den gamle mytografis hermeneutiske ordflom, hævder Lévi-Strauss. Myterne udgør et universelt sprog, som det samtidig ikke er muligt at oversætte til noget andet end sig selv. Man kan så fundere over om Lévi-Strauss' problemer med at „oversætte“ myterne skyldes mytens natur eller de metoder, som han har valgt. Men faktisk er Lévi-Strauss' konklusion en meget præcis karakteristik af hans egen praksis. De arkaiske kulturers gådefulde myter er blevet oversat til en moderne scientistisk myte, der ikke lader den anden meget efter i gådefuldhed. Myteanalysen er blevet opslugt af myten.

\section{Epilog}

Jeg har ingen prætentioner om, at denne lille tekst skulle ændre noget som helst ved den danske kritiks opfattelse af Lévi-Strauss. Deri ligger der en pointe. Implicit viser min artikel det samme som Sokals practical joke med tidsskriftet Social text: ${ }^{24}$ i det usikre og vage felt, der hedder humaniora, er det, der tæller, ikke så meget en idés indhold som dens oprindelse. En anerkendt forsker kan slippe af sted med det rene vås, for der behøves kun en prestigefyldt signatur for at det bliver alment accepteret. Følgesætning: konsistente teorier fremsat af ikke-autoriserede forskere kan ikke anerkendes.

Når det er idéernes ophav og ikke deres indhold, der tæller, når et lærd tidsskrift som Social Text så let lader sig narre, hvor skal man så trække grænsen mellem videnskab og ideologi? I de hårde videnskaber er det muligt at afsløre svindel og inkonsistente teorier: er forsøget reproduktibelt? Men hvordan er det muligt inden for humaniora at skelne geniet fra charlatanen eller fra galningen? Hvordan skal man afprøve ordene, begrebsappara- 
tet, synsvinklen? Og hvordan kan man modbevise dem?25 Man kan kun bruge andre ord, et andet begrebsapparat, en anden synsvinkel. Det, der til syvende og sidst afgør sagen, er simpelt hen styrkeforholdet mellem de forskellige kirkefædre. Jo mere en forfatter bliver citeret, jo mere vægt har hans ord, og jo sandere er hans lære. Sandheden stiller sig på samme side som de store bataljoner, nøjagtig som Gud gjorde det førhen for Frederik d. 2. af Prøjsen.

At få succes for en mediciner er at frembringe en verificerbar sandhed. At få succes for en humanistisk videnskabsmand er at tilkæmpe sig rollen som uomgængelig reference. En teori er rigtig, fordi Barthes, Foucault, Lévi-Strauss, Greimas, Paul de Man etc. har fremsat den. De humanistiske forskere ville være videnskabsmænd og ikke ideologer. Deres produktion skulle være resultater og ikke doktriner. Men de humanistiske videnskaber er rent faktisk endt der, hvor de for alt i verden ikke ville ende: på linie med den religiøse og ideologiske diskurs.

\section{Bibliografi}

Chomsky, Noam: Current Issues in Linguistic Theory, Den Haag, Mouton, 1969.

Fischer-Jørgensen, Eli: Trends in Phonological Theory, København, Akademisk Forlag, 1975

Gregersen, Frans: Mellem historisme og strukturalisme, festforelæsning på Københavns Universitet den 20. september 1994.

Lévi-Strauss, Claude: Anthropologie structurale, Paris, Plon, 1958.

- Le cru et le cuit, Paris, Plon, 1964.

- L'Homme nu, Paris, Plon, 1971.

Ricœur, Paul: Le Conflit des interprétations, Paris, Seuil, 1969.

Saussure, Ferdinand de: Cours de linguistique générale, Paris, Payot, 1967. Trubetzkoy, N.: Principles of Phonology, University of California Press, 1969.

\section{Noter}

1. En tidligere udgave af denne artikel har været trykt i udgivelsesserien RIDS for Romansk Institut på Københavns Universitet.

2. Bortset fra A. J. Greimas, der faktisk har lavet en oldfransk ordbog.

3. Claude Lévi-Strauss, Anthropologie structurale, Paris, Plon, 1958, p. 37.

4. „le patron de toute sémiologie, Ferdinand de Saussure, Cours de linguistique générale, "Paris, Payot, 1967, p.33.

5. Artiklen, der første gang blev trykt i 1945, findes i Anthropologie structurale, Paris, Plon, 1958.

6. investigate which phonic differences are linked, in the language under consideration, with differences of meaning, how these differentiating elements or marks are related to one another, and according to what rule they combine to form words and phrases.", N. Trubetzkoy, Principles of Phonology, University of California Press, 1969, p. 11-12.

7. Paul Ricœur, Le Conflit des interprétations, Paris, Seuil, 1969.

8. , „... s'il était possible de démontrer que, dans ce cas aussi, l'apparence arbitraire, le jaillissement prétendu libre, l'invention qu'on pourrait croire débridée, supposent des lois opérant à un niveau plus profond, la conclusion deviendrait inéluctable que l'esprit livré au tête-à-tête avec lui-même et échappant à l'obligation de composer avec les objets, se trouve en quelque sorte réduit à s'imiter lui-même comme objet; et que, les lois de ses opérations n'étant pas alors fondamentalement différentes de celles qu'il manifeste dans l'autre fonction, il avère ainsi sa nature de chose parmi les choses." Claude Lévi-Strauss, Le cru et le cuit, Paris, Plon 1964, p. 18.

9. Claude Lévi-Strauss, Anthropologie structurale, Paris, Plon, 1958, p. 40. 
10. Frans Gregersen, "Mellem historisme og strukturalisme”, festforelæsning $\mathrm{i}$ anledning af overrækkelsen af Ejner Hansens forskningspris for året 1994 på Københavns Universitet den 20. september 1994.

11. Claude Lévi-Strauss, Anthropologie structurale, p. 236

12. „Il exprimerait l'impossibilité se trouveé une société qui professe de croire à l'autochtonie de l'homme [...] de passer, de cette théorie, à la reconnaissance du fait que chacun de nous est réellement né de l'union d'un homme et d'une femme." Claude Lévi-Strauss, Anthropologie structurale, p. 239.

13. Selvom Chomsky generative grammatik ikke spiller nogen rolle for strukturalismen, så er hans arbejde en præcis kortlægning af hvad det er, den strukturelle lingvistik egentlig gør, hvor dens styrke såvel som dens svagheder findes.

14. En dyberegående analyse af Chomskys kritik af Bloomfield og pragerskolens fonologi findes i Eli Fischer-Jørgensen, Trends in Phonological Theory, København, Akademisk Forlag, 1975, pp. 281-184, som Ole Kongsdal Jensen venligst har henledt min opmærksomhed på.

15. „,a general linguistic theory must incorporate a universal phonetic theory, with a fixed alphabet." Noam Chomsky, Current Issues in Linguistic Theory, Den Haag, Mouton, 1969, p. 67.

16. „The linearity condition requires that each occurrence of a phoneme in the phonemic representation of an utterance be associated with a particular succession of (one or more) consecutive phones in its representing matrix, as its "member" or "realization"; and, furthermore, that if A precedes $B$ in the phonemic representation, then the phone sequence associated with $A$ prededes (is to the left of) that associated with $B$ in the phonetic matrix". Ibid., p.78.

17. Af mangel på en passende terminologi vil jeg her fortsætte med at bruge de lingvistiske termer fonetisk og fonologisk om de forskellige beskrivelsesniveauer.

18. „The invariance condition asserts that each phoneme $P$ has associated with it a certain set $\Psi(\mathrm{P})$ of defining features (that is, $\mathrm{P}=\mathrm{Q}$ if and only if $\Psi_{(\mathrm{P})}=\varphi_{(\mathrm{Q})}$ and that wherever $\mathrm{P}$ occurs in a phonemic representation, there is an associated occurrence of $\varphi_{(\mathrm{P})}$ in the corresponding phonetic representation." Noam Chomsky, Op. cit., p. 79.

19. "The invariance condition has no clear meaning unless the linearity condition is also met," Loc. cit.

20. „each sequence of phones is represented by a unique sequence of phonemes, and that each sequence of phonemes represents a unique sequence of phones." Noam Chomsky, Current Issues in Linguistic Theory, Den Haag, Mouton, 1969, p. 80.

21 „such that the unique phonemic representation corresponding to a given phonetic form can be determined by „purely phonetic” considera- tions or perhaps, considerations involving only neighbouring sounds". Loc. cit.

22. Claude Lévi-Strauss, Anthropologie structurale, Paris, Plon, 1958, p. 240.

23. „Les mythes sont seulement traduisibles les uns dans les autres, de la même façon qu'une mélodie n'est traduisible qu'en une autre mélodie qui préserve avec elle des rapports $\mathrm{d}^{\prime}$ homologie. [...] Mais si on peut toujours $[. .$.$] traduire une mélodie en une autre mélodie, [. .$.$] comme dans le$ cas de la mythologie on ne peut traduire la musique en autre chose qu'ellemême, sous peine de sombrer dans le verbiage à prétention herméneutique de l'ancienne mythographie et de la critique musicale trop souvent. Ainsi, une liberté illimitée de traduction dans les dialectes d'une langue originelle formant un univers étanche va de pair avec l'impossibilité radicale de toute transposition dans un langage extrinsèque." Claude Lévi-Strauss, L'Homme nu, Paris, Plon, 1971, pp. 577-578.

24. Den amerikanske fysikprofessor Alan Sokal fik i 1996 optaget en artikel i Social Text. Denne artikel parodierede groft de artikler, som tidsskriftet normalt trykte med det formål at diskreditere den postmodernistiske relativisme, der udgør tidsskriftets grundholdning.

25 . Det er kun muligt at vise uoverensstemmelserne mellem LéviStrauss' epistemologiske grundlag og hans analytiske praksis, fordi grundlaget netop er så usædvanlig stringent formuleret. 